\title{
Health Seeking Behaviour pada Pasien Stroke
}

\section{Health Seeking Behavior on Stroke Patients}

\author{
Tita Hariyanti ${ }^{1}$, Harsono ${ }^{2}$, Yayi S Prabandari ${ }^{2}$ \\ ${ }^{1}$ Laboratorium IImu Kesehatan Masyarakat Fakultas Kedokteran Universitas Brawijaya Malang \\ ${ }^{2}$ Fakultas Kedokteran Universitas Gadjah Mada Yogyakarta
}

\begin{abstract}
ABSTRAK
Studi pendahuluan, menunjukkan hasil bahwa pasien stroke yang datang di rumah sakit dalam waktu 3 jam sejumlah $<34 \%$. Lebih dari 35\% pasien tiba di rumah sakit diatas 24 jam. Fakta ini dapat merupakan fenomena gunung es, yaitu masih banyak pasien stroke yang tidak dibawa ke rumah sakit dengan berbagai alasan. Tujuan penelitian ini adalah untuk mengetahui perilaku pasien stroke dalam mencari pertolongan kesehatan sehubungan dengan penyakitnya. Disain penelitian ini adalah deskriptif observasional. Penelitian ini menggunakan 101 pasien stroke yang ada di masyarakat Kecamatan Kepanjen. Responden diperoleh dari penelusuran berkas rekam medik pasien stroke dan informasi dari mulut ke mulut (snowball sampling). Hasil menunjukkan bahwa 31,5\% pasien langsung datang ke rumah sakit ketika terkena stroke dengan rentang waktu bervariasi. Pasien stroke yang pergi ke rumah sakit dalam waktu 3 jam sebesar 18,7\%, sedangkan sisanya tiba dalam waktu $>3$ jam. Pasien yang diperiksakan ke petugas kesehatan terlebih dulu, kemudian dibawa ke rumah sakit adalah sebesar $46,5 \%$, dan pasien yang tidak dibawa ke rumah sakit setelah dibawa ke petugas kesehatan maupun non kesehatan sebesar $22 \%$. Health seeking behaviour ini dipengaruhi oleh beberapa faktor yaitu faktor demografi dan geografi, sosio-budaya, klinis, persepsi, dan pengetahuan. Dapat disimpulkan bahwa terdapat 3 alur health seeking behaviour pada pasien stroke yang ada di masyarakat, yaitu langsung ke rumah sakit, ke rumah sakit setelah dibawa ke petugas kesehatan atau non petugas kesehatan, dan tidak pergi ke rumah sakit setelah dibawa ke petugas kesehatan atau non petugas kesehatan.
\end{abstract}

Kata Kunci: Deskriptifobservasional, health seeking behaviour, stroke

\begin{abstract}
Preliminary studies show that stroke patients arriving at the hospital within 3 hours were less than 34\% and more than 35\% patients arrived at the hospital after 24 hours. This fact is an iceberg phenomenon which means a lot of stroke patients were not taken into hospital with various reasons. This study purposely wants to determine the behavior of stroke patients in health seeking related to the disease. The design of this study was observational descriptive. This study utilized 101 stroke patients in Kepanjen Subdistrict. Respondents were obtained from stroke patients' medical records and information by word of mouth (snowball sampling). The results show that 31,5\% patients came to the hospital immediately with various time spans. Stroke patients who went to the hospital within 3 hours were $18,7 \%$, while the rest arrived after more than 3 hours. Patients who were examined by health workers first then taken to the hospital were 46,5\%, and patients were not taken to hospital after being taken to the medical and non-medical personnel were $22 \%$. Health seeking behavior was influenced by several factors, namely demographic and geographic factors, socio-cultural, clinical, perception, and knowledge. It can be concluded that there are three pathways of health-seeking behavior in stroke patients in the community, i.e.go directly to the hospital, go the hospital after being taken to a health worker or non-health workers, and do not go to the hospital after being taken to the officer health or non-health care workers.
\end{abstract}

Keywords:observational descriptive, health seeking behavior, stroke

Jurnal Kedokteran Brawijaya, Vol. 28, No. 3, Februari 2015; Korespondensi: Tita Hariyanti. Laboratorium Ilmu Kesehatan Masyarakat Fakultas Kedokteran Universitas Brawijaya Malang, Jl. Veteran Malang Tel. (0341)569117Email: tita_widodo@yahoo.com 


\section{PENDAHULUAN}

Penyakit degeneratif dengan tingkat morbiditas dan mortalitas yang tinggi adalah penyakit vaskular. Penyakit jantung koroner (PJK) dan stroke termasuk penyakit vaskular dengan tingkat mortalitas tinggi. Menurut Departemen Kesehatan (Depkes), stroke menempati urutan pertama dari 10 penyakit degeneratif terbanyak di Indonesia (1). Selain angka mortalitas stroke menempati urutan tertinggi, angka kesakitan stroke juga menempati urutan ketiga di dunia. Penyakit stroke dengan gejala yang sangat bervariasi, sering sulit dikenali oleh kalangan petugas kesehatan sekalipun (2). Banyak terjadi keterlambatan penanganan kasus stroke yang disebabkan oleh pengetahuan yang kurang dari pasien, keluarganya, maupun petugas kesehatan yang menangani (3).

Tingginya angka morbiditas stroke ini tidak hanya terjadi di dunia internasional, tetapi juga Kabupaten Malang. Pada bulan September 2010, penulis melakukan studi pendahuluan di 3 rumah sakit yang ada di Kecamatan Kepanjen Kabupaten Malang, yaitu rumah sakit umum swasta, rumah sakit umum pemerintah dan rumah sakit khusus geriatri. Penelitian pendahuluan tersebut dilakukan dengan menggunakan cara penelusuran berkas rekam medik pasien stroke, tanpa membedakan jenisnya (perdarahan atau penyumbatan).

Dari penelitian tersebut didapatkan hasil bahwa terdapat $<10 \%$ pasien yang dibawa ke rumah sakit dalam keadaan meninggal dunia. Dilihat dari usia, sebagian besar (46\% $52 \%$ ) pasien berusia $<60$ tahun atau pralansia dan laki-laki lebih banyak dibandingkan perempuan (55\% - 60\%) dengan perbedaan yang tidak terlalu besar. Pasien stroke yang masuk rumah sakit ini sebagian besar tidak bekerja. Studi ini juga menunjukkan bahwa pasien stroke yang dibawa ke rumah sakit $\leq 3$ jam sejak dari timbulnya gejala sebanyak $\leq 35 \%$, sedangkan sisanya telah melewati golden period(masa yang tidak boleh terlewati oleh pasien stroke agar dapat ditolong lebih dini) yaitu $\leq 3 \mathrm{jam}$.

Fenomena ini hampir sama dengan keadaan di Amerika yaitu bahwa $<50 \%$ pasien stroke mencari pertolongan dalam waktu $\leq 3 \mathrm{jam}, 30 \%>3$ jam, sedangkan sekitar $20 \%$ lebih dari 24 jam (3). Menurut Moser (4), keterlambatan pasien stroke dalam mencari pertolongan dibagi menjadi 3 tahapan, yaitu: (a) saat mulai timbulnya gejala pertama sampai memutuskan untuk mencari pertolongan (3 jam), (b) saat pasien atau keluarganya memutuskan untuk mencari pertolongan sampai dengan bertemu dengan petugas kesehatan (10 jam) (5), dan (c) saat pasien telah kontak dengan petugas kesehatan sampai pasien akhirnya masuk rumah sakit (2 jam). Dari ketiganya, tahap yang paling lama adalah pada saat keluarga memutuskan mencari pertolongan sampai dengan bertemu dengan petugas kesehatan (4).

Penulis tertarik untuk melakukan studi yang sama di Kecamatan Kepanjen, Kabupaten Malang. Tujuan penulisan ini adalah ingin mengetahui perilaku mencari pertolongan kesehatan (health seeking behaviour) pada pasien stroke mulai timbulnya gejala hingga pasien dibawa ke rumah sakit, sehingga dapat mengurangi keterlambatan penderita stroke dan angka kecacatan serta kematian akibat stroke berkurang.

\section{METODE}

Disain penelitian ini adalah deskriptif observasional. Penelitian dilakukan terhadap 101 pasien stroke di masyarakat. Responden penulisan ini adalah pasien stroke itu sendiri atau keluarga dekat pasien. Metode pengambilan sampel ini melalui penelusuran berkas rekam medik pasien stroke di Rumah Sakit Khusus Geriatri di Kecamatan Kepanjen Kabupaten Malang, sebagai salah satu rumah sakit yang memberikan pelayanan tentang stroke. Pasien stroke yang ditemukan alamatnya, kemudian memberikan informasi tentang pasien stroke lain yang tinggal disekitarnya untuk dapat diwawancarai (snowball sampling). Alasan penulis mencari pasien stroke di masyarakat adalah bahwa pasien stroke yang sedang atau telah dirawat di rumah sakit diduga telah mempunyai kesadaran yang lebih baik dibandingkan pasien stroke yang di masyarakat.

\section{HASIL}

\section{Karakteristik Responden}

Responden yang bersedia diwawancarai sejumlah 112 responden, tetapi beberapa orang tidak yakin akan kebenaran informasi yang diberikan sehingga hanya 101 responden yang terkumpul. Tabel 1 menunjukkan bahwa persentase pasien yang terkena stroke pada usia 51-60 $(30,7 \%)$ sama banyak dengan pasien yang berusia $61-70$ $(30,7 \%)$. Penelitian juga menunjukkan bahwa perempuan lebih banyak (58.7\%) terkena stroke dibandingkan laki-laki. Sebagian besar pasien (80\%) menderita stroke sebagai serangan pertama. Gejala yang menonjol dari responden adalah kelumpuhan separuh badan $(57,4 \%)$ dengan proporsi terbanyak $(65,4 \%)$ saat serangan adalah saat beraktivitas.

Tabel 1. Karakteristik pasien stroke di masyarakat Kecamatan Kepanjen $(n=101)$

\begin{tabular}{|c|c|c|c|}
\hline No & Variabel & Frekuensi & $\%$ \\
\hline \multirow[t]{7}{*}{1.} & Umur & & \\
\hline & $30-40$ tahun & 5 & 5 \\
\hline & $41-50$ tahun & 21 & 20,8 \\
\hline & $51-60$ tahun & 31 & 30,7 \\
\hline & $61-70$ tahun & 31 & 30,7 \\
\hline & $71-80$ tahun & 10 & 9,9 \\
\hline & $>81$ tahun & 3 & 3 \\
\hline \multirow[t]{3}{*}{2.} & Jenis Kelamin & & \\
\hline & Laki-laki & 40 & 38,5 \\
\hline & Perempuan & 61 & 58,7 \\
\hline \multirow[t]{4}{*}{3.} & Serangan ke & & \\
\hline & Pertama & 79 & 76 \\
\hline & Kedua & 17 & 16,3 \\
\hline & Lebih dari dua kali & 5 & 4,8 \\
\hline \multirow[t]{7}{*}{4.} & Keluhan utama & & \\
\hline & Lemah separuh badan & 58 & 57,4 \\
\hline & Gringgingen & 15 & 14,8 \\
\hline & Tidak bisa bicara (afasia) & 3 & 2,9 \\
\hline & Tidak jelas bicara & 7 & 6,7 \\
\hline & (disartria) & 18 & 17,8 \\
\hline & Lainnya & & \\
\hline \multirow[t]{5}{*}{5.} & Aktivitas saat serangan & & \\
\hline & Bangun tidur & 17 & 16,3 \\
\hline & Berbaring & 11 & 10,6 \\
\hline & Duduk & 5 & 4,8 \\
\hline & Aktivitas & 68 & 65,4 \\
\hline
\end{tabular}

\section{Perilaku Mencari Pertolongan}

Tabel 2 menunjukkan bahwa pasien yang terkena stroke dengan berbagai gejala menunjukkan perilaku yang 
berbeda. Terdapat beberapa perilaku pasien saat menderita stroke, yaitu: 1) langsung dibawa ke rumah sakit (alur pertama), 2) dibawa ke rumah sakit, setelah sebelumnya dibawa ke petugas kesehatan (dokter, perawat, bidan) maupun non petugas kesehatan (tukang pijat, pengobatan herbal, paranormal) (alur kedua), 3) dibawa ke petugas kesehatan dan non petugas kesehatan, tanpa dibawa ke rumah sakit (alur ketiga).

Tabel 2. Alur health seeking behaviour pasien stroke di masyarakat $(n=101)$

\begin{tabular}{|c|c|c|c|}
\hline No & Variabel & Frekuensi & Persen \\
\hline \multicolumn{2}{|r|}{$\begin{array}{l}\text { 1. Alur pertama (langsung dibawa ke rumah } \\
\text { sakit) }\end{array}$} & 32 & 31,5 \\
\hline \multicolumn{2}{|r|}{$<1$ jam } & 13 & 12,8 \\
\hline \multicolumn{2}{|r|}{$1-3$ jam } & 6 & 5,9 \\
\hline \multicolumn{2}{|r|}{$>3$ jam } & 13 & 12,8 \\
\hline \multicolumn{2}{|r|}{$\begin{array}{l}\text { 2. Alur kedua (dibawa ke rumah sakit } \\
\text { setelah sebelumnya dibawa ke-) }\end{array}$} & 47 & 46,5 \\
\hline \multicolumn{2}{|r|}{ a. Petugas kesehatan } & 39 & 38,6 \\
\hline \multicolumn{2}{|r|}{ Dokter } & 8 & 7,9 \\
\hline \multicolumn{2}{|r|}{ Perawat } & 27 & 26,7 \\
\hline \multicolumn{2}{|r|}{ Bidan } & 3 & 2,9 \\
\hline \multicolumn{2}{|r|}{ b. Non petugas kesehatan } & 8 & 7,9 \\
\hline \multicolumn{2}{|r|}{ Tukang pijat } & 5 & 4,9 \\
\hline \multicolumn{2}{|r|}{ Paranormal } & 2 & 1,9 \\
\hline \multicolumn{2}{|r|}{ Pengobatan herbal } & 1 & 0,9 \\
\hline \multicolumn{2}{|r|}{$\begin{array}{l}\text { 3. Alur ketiga (dibawa ke petugas kesehatan } \\
\text { atau non kesehatan tanpa dibawa ke } \\
\text { rumah sakit }\end{array}$} & 22 & 21,8 \\
\hline
\end{tabular}

Sumber: Studi pendahuluan

Pada alur pertama, sebesar $31,5 \%$ pasien stroke langsung dibawa ke rumah sakit. Dari populasi ini, 12,5\% dibawa dalam waktu $<1$ jam, 5,8\% 1-3 jam, dan 12,5\% >3 jam. Sebesar $46,5 \%$ pasien stroke melalui alur kedua. Alur kedua ini menunjukkan bahwa pasien dibawa ke rumah sakit, setelah sebelumnya dibawa ke petugas kesehatan $(38,6 \%)$ maupun non petugas kesehatan $(7,9 \%)$. Petugas kesehatan yang dimaksud dalam penelitian ini adalah dokter, perawat, dan bidan, sedangkan yang dimaksud dengan non petugas kesehatan adalah tukang pijat, pengobatan herbal, dan paranormal. Gambaran alur tersebut diatas dapat dilihat sebagai bagan alur (Gambar $1)$.

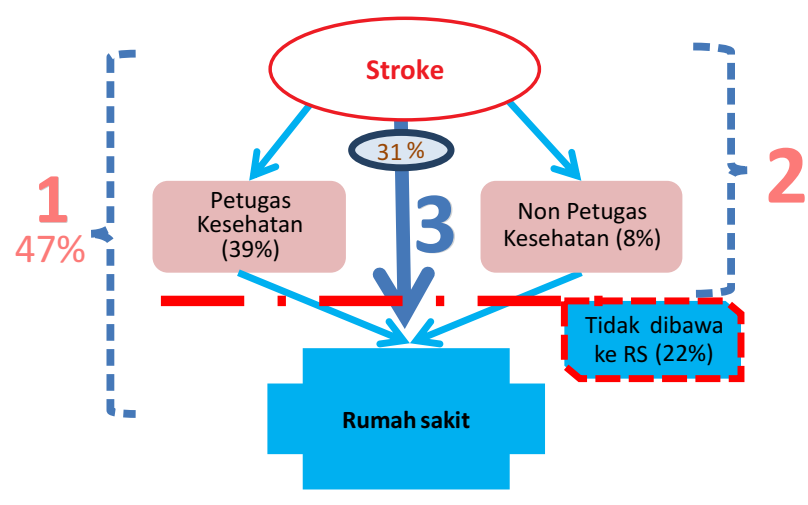

Gambar 1. Pola health seeking behaviour pada pasien stroke

\section{DISKUSI}

\section{Karakteristik Penderita Stroke}

Di negara-negara berkembang, seperti India, Indonesia, Saudi Arabia, 15-30\% stroke terjadi pada usia muda (5). Dalam penelitian ini, sekitar $25 \%$ pasien berusia dibawah 50 tahun. Secara garis besar, faktor risiko stroke dibagi menjadi 2 golongan besar, yaitu faktor risiko yang tidak dapat diubah dan dapat diubah. Faktor risiko yang tidak dapat diubah terdiri dari usia, ras, jenis kelamin, dan riwayat stroke sebelumnya. Faktor risiko yang dapat diubah merupakan sasaran terapetik pada pasien stroke pasca akut. Faktor risiko ini terdiri dari faktor risiko mayor (hipertensi, kelainan jantung, dan diabetes mellitus) dan minor (hiperlipidemi, merokok, inaktivitas fisik, konsumsi alkohol, dll). Manajemen faktor risiko pada penderita stroke bertujuan untuk prevensi sekunder (pencegahan kejadian stroke berikutnya) dan melibatkan berbagai multidisiplin dalam bidang ilmu kedokteran (6). Sepanjang faktor risiko dapat dikendalikan dengan upaya tertentu, maka pengendalian tersebut akan mengurangi angka kejadian stroke (7).

Banyak faktor yang menyebabkan terjadinya stroke di usia muda, salah satunya adalah health seeking behaviour. Terdapat perbedaan health seeking behaviour pada pria dan wanita. Sekitar $10 \%$ pria berusia $45-65$ tahun pergi ke dokter 3 tahun sekali, sedangkan $44 \%$ konsultasi 2 kali dalam setahun. Laki-laki lebih jarang mencari pertolongan kesehatan jika sakit dibandingkan dengan perempuan pada semua usia dan jenis penyakit dengan alasan maskulinitas (8). Hasil dari penelitian ini menunjukkan bahwa pasien stroke wanita lebih banyak daripada pria. Secara epidemiologis, jumlah penduduk wanita memang lebih banyak dibandingkan pria, dengan angka harapan hidup wanita lebih panjang (1). Salah satu faktor risiko stroke pada wanita adalah penggunan kontrasepsi oral (5), sehingga faktor tersebut pulalah yang dapat menyebabkan terjadinya stroke pada wanita lebih banyak. Pada kasus stroke, efeknya lebih berat pada wanita karena lebih sulit untuk sembuh (11). Usia juga membuat seseorang lebih lambat dalam mencari pertolongan, karena pada usia tua orang akan menunggu diberi advis dari keluarganya (12).

Gejala yang paling sering terjadi pada penelitian ini adalah kelumpuhan pada anggota tubuh sesisi. Menurut Ranakusuma, pada umumnya manifestasi klinis serangan otak dapat berupa: (1) baal, kelemahan atau kelumpuhan pada wajah, lengan, atau tungkai sesisi ata kedua sisi dari tubuh, (2) penglihatan tiba-tiba kabur atau menurun, (3) gangguan bicara dan bahasa atau pengertian dalam komunikasi, (4) dizziness, gangguan keseimbangan atau cenderung mudah terjatuh, (5) kesulitan menelan, (5) sakit kepala yang hebat secara tiba-tiba, (6) delirium atau kesadaran berkabut (sudden confusion). Proses patologis yang terjadi dapat berupa perdarahan (20\%) dan iskemia (80\%). Biasanya manifestasi klinis gangguan fungsi otak pada perdarahan lebih berat oleh karena selain proses iskemia, didapatkan pula proses desak ruang (hematoma) (11)

\section{Perilaku Mencari Pertolongan}

Menurut Mustafa, pikiran, perasaan, sikap (proses mental) bukan sesuatu yang bisa menjelaskanperilaku seseorang. Kita tidakbisa memahami perilaku seseorang tanpa mempelajari proses mental mereka. Manusia tidak menanggapi lingkungannya secara otomatis. Perilaku 
mereka tergantung pada bagaimana mereka berpikir dan mempersepsi lingkungannya. Jadi untuk memperoleh informasi yang bisa dipercaya maka proses mental seseorang merupakan hal utama yang bisa menjelaskan perilaku sosial seseorang (12).

Terdapat beberapa faktor yang dapat mempengaruhi perilaku kesehatan seseorang, antara lain geografis dan demografi. Faktor geografi seperti jarak antara rumah penderita dengan petugas kesehatan terdekat dapat mempengaruhi perilaku mencari pertolongan kesehatan. Selain itu, faktor jenis kelamin dan pendidikan rendah juga berpengaruh terhadap keterlambatan mencari pertolongan (13).

Tidak adanya gejala kelumpuhan anggota gerak, pusing, gangguan bicara, sakit kepala, menyebabkan seseorang tidak mengetahui bahwa dirinya terkena stroke dan tidak segera memutuskan mencari pertolongan kesehatan (14). Riwayat terkena diabetes, hipertensi, jantung koroner akan membuat orang lebih berhati-hati terhadap gejala stroke dibandingkan dengan yang tidak mempunyai riwayat penyakit tersebut (10). Oleh karena itu faktor klinis ini juga dapat berpengaruh terhadap perilaku mencari pertolongan.

Selain faktor geografis, demografis, dan klinis, terdapat juga faktor sosio-budaya. Hidup sendiri sering menjadikan hambatan dalam mencari pertolongan kesehatan (13). Kemudian, ada pula budaya setempat tentang menyikapi gejala sakit, bahwa orang cenderung mengobati diri sendiri dulu, kemudian baru mencari pertolongan kesehatan, baik ke ahli pengobatan tradisional maupun ke tenaga kesehatan professional (15).

Persepsi tentang kerentanan daya tahan tubuhnya, kegawatan proses penyakitnya, hambatan terhadap perilaku mencari pertolongan akan membuat seseorang terlambat melakukan kontak dengan petugas kesehatan (16). Faktor lain yang mempengaruhi pencarian pertolongan kesehatan adalah pengetahuan. Health seeking behaviour ini sangat dipengaruhi oleh pengetahuan, sikap, norma, dan nilai yang dianut seseorang terhadap sesuatu (18/17). Pengetahuan yang kurang akan menyebabkan kesadaran seseorang akan stroke rendah, sehingga penderita stroke akan terlambat dibawa ke rumah sakit untuk mendapatkan pertolongan (18).

Pada penelitian ini, terdapat 3 alur yang menunjukkan perilaku pasien stroke dalam mencari pertolongan kesehatan. Alur pertama adalah pasien stroke langsung dibawa ke rumah sakit tanpa dibawa kemanapun sebelumnya. Semua pasien stroke yang langsung dibawa ke rumah sakit ini adalah stroke tipe perdarahan, oleh karena gejala yang muncul pada tipe perdarahan lebih berat dibanding tipe infark. Gejala yang paling sering muncul adalah pasien tidak sadarkan diri (11). Keadaan tidak sadarkan diri ini sering membuat panik keluarga sehingga pasien stroke dibawa ke rumah sakit sesegera

\section{DAFTAR PUSTAKA}

1. Kementerian Kesehatan Republik Indonesia. Profil Kesehatan Indonesia 2010. Jakarta: Kementerian Kesehatan Republik Indonesia; 2011.

2. Misbach J. Stroke: Aspek Diagnostik, Patofisiologi, Manajemen. Jakarta: Gramedia Pustaka Utama; 2011.

3. Finke EH, Light J, and Kitko L. The Effectiveness of mungkin. Perilaku keluarga untuk membawa pasien stroke langsung ke rumah sakit $\leq 3 \mathrm{jam}$, disebut sebagai perilaku baik atau sesuai. Keluarga yang tidak segera membawa pasien stroke ke rumah sakit $\leq 3$ jam disebut dengan berperilaku buruk (11).

Alur kedua, pasien stroke dibawa ke rumah sakit setelah sebelumnya diperiksakan ke petugas kesehatan atau non petugas kesehatan terlebih dahulu. Lebih dari sepertiga kasus stroke diperiksakan ke petugas kesehatan terlebih dulu sebelum dibawa ke rumah sakit. Petugas kesehatan ini meliputi dokter, perawat, dan bidan. Dari ketiga profesi petugas kesehatan tersebut, yang paling sering kontak dengan orang sakit di masyarakat adalah perawat. Biasanya, pasien dan keluarganya ingin memastikan dulu penyebab timbulnya gejala, sebelum membawa ke rumah sakit. Menurut beberapa responden, mereka lebih nyaman dengan perawat karena para perawat tersebut bersedia dipanggil ke rumah.

Sebagian kecil responden mengaku pergi ke non petugas kesehatan sebelum membawa pasien stroke ke rumah sakit. Salah satu responden yang berprofesi sebagai penyanyi, mengaku dia pergi ke paranormal ketika satu hari sebelumnya tiba-tiba timbul gejala wajah yang tidak simetris. Responden berpendapat bahwa penyakit yang dideritanya ini adalah 'penyakit kiriman' dari orang yang tidak suka padanya.Setelah beberapa minggu tidak ada tanda-tanda perbaikan dari penyakitnya, paranormal itu sendiri yang kemudian menyarankan untuk memeriksakan ke rumah sakit. Keyakinan akan penyebab penyakit, merupakan faktor predisposisi yang dapat mempengaruhi perilaku (16).

Alur terakhir adalah alur pasien stroke yang setelah dibawa ke petugas kesehatan maupun non petugas kesehatan, tidak dibawa ke rumah sakit. Ada banyak faktor yang menyebabkan seseorang tidak segera membawa pasien stroke ke rumah sakit. Beberapa diantaranya adalah jarak dari rumah ke rumah sakit, kondisi sosio-ekonomi, dan pengetahuan petugas tentang stroke yang kurang. Pada beberapa kasus, keluarga mengaku telah memeriksakan pasien stroke ke dokter, namun oleh dokter tidak dirujuk ke rumah sakit. Dokter, perawat, dan bidan sebagai petugas kesehatan yang diharapkan dapat sebagai 'penggerak' (cues to action) untuk merubah health seeking behavior (16) tidak melakukan tugasnya karena keterbatasan pengetahuannya.

Hasil penelitian ini membuktikan terdapat 3 alur health seeking behaviour pada orang stroke, yaitu langsung ke rumah sakit, pergi ke rumah sakit setelah dibawa ke petugas kesehatan atau non petugas kesehatan, dan tidak pergi ke rumah sakit meski telah dibawa ke petugas kesehatan maupun non petugas kesehatan. Ketiga alur terjadi karena mungkin dipengaruhi oleh geografis dan demografis, klinis, sosio-budaya, persepsi, dan pengetahuan, baik dari masyarakat maupun petugas kesehatan.

Nurse Communication with Patients with Complex Communication Needs: A Systematic Review and Focus on the Augmentative and Alternative Communication. Journal of Clinical Nursing. 2008; 17(6): 2102-2115.

4. Alberts MJ, Perry A, Dawson DV, and Bertels C. Effects of Public and Professional Education on Reducing the Delay in Presentation and Referral of Stroke Patients. 
Stroke. 1992; 23(3): 352-356.

5. Kisjanto J. Risk Factors for Stroke in Young Indonesian Women. (O n I i n e ) 1996 . http://repub.eur.nl/pub/22509/960605_Kisjanto,\%2 OJahja.pdf

6. Andersen KK, Andersen ZJ, and Olsen TS. Age-and Gender-Spesific Prevalence of Cardiovascular Risk Factors in 40.102 Patients with First - Ever Ischemic Stroke: A Nationwide Danish Study. Stroke. 2010; 41(12): 2768-2774

7. Harsono. Kapita Selekta Neurologi. Edisi Kedua. Yogyakarta: Gadjah Mada University Press; 2005.

8. Galdas P, Cheater F, and Marhall P. Men and HeatlhHelp Seeking Behaviour: Literature Review. Journal of Advanced Nursing. 2005; 49(6): 616-623.

9. Reeves MJ. Reducing The Delay Between Stroke Onset And Hospital Arrival: Is It An Achievable Goal? Journal of the American Heart Association. 2012; 1: e002477

10. Smith MA, Doliszny KM, Shahar E, McGovern PG, Arnett DK, and Luepker RV. Delayed Hospital Arrival for Acute Stroke: The Minnesota Stroke Survey. Annals of Internal Medicine. 1998; 129(3): 190-196.

11. No Author Listed. Updates in Neuroemergencies. Jakarta: Balai Penerbit FKUI; 202.

12. Mustafa H. Perilaku Manusia dalam Perspektif
Psikologi Sosial. Jurnal Administrasi Bisnis. 2011; 7(2): 143-156.

13. Tan TY, Chang KC, and Liou CW. Factors Delaying Hospital Arrival after Acute Stroke in Southern Taiwan. Chang GungMedicalJournal. 2002; 25(7): 458-463.

14. Mandelzweig L, Goldbourt U, Boyko V, and Tanne D. Perceptual, Social, and Behavioral Factors Associated with Delays in Seeking Medial Care in Patiens with Symptoms of Acute Stroke. Stroke. 2006; 37(5): 12481253.

15. Yanagisawa S, Mey V, and Wakai S. Comparison of Health-Seeking Behaviour between Poor and BetterOff People after Health Sector Reform lin Cambodia. Public Health. 2004; 118(1): 21-30.

16. Glanz K, Rimer BK, and Viswanath K. Health Behavior and Health Education: Theory, Research, and Practice. 4th edition. San Francisco: Jossey-Bass A Wiley Imprint; 2008.

17. Lindbladh $\mathrm{E}$ and Lyttkens $\mathrm{CH}$. Habit versus Choice: The Process of Decission-Making in Health-Related Behaviour. Social Science and Medicine. 2002; 55(3): 451-465.

18. Kim YS, Park S, Bae H, et al. Stroke Awareness Decreases Prehospital Delay after Acute Ischemic Stroke in Korea. BioMed Central Neurology. 2011; 11: 2. 